\title{
Management of Tannery Solid Waste (TSW) through Pyrolysis and Characteristics of Its Derived Biochar
}

\author{
Hajira Younas, Aisha Nazir, Firdaus-e-Bareen* \\ Department of Botany, University of the Punjab, Lahore-54590, Pakistan
}

Received: 13 December 2019

Accepted: 29 January 2020

\begin{abstract}
Tannery solid waste is problematic and toxic biomass that has no other use than being dumped into the landfill or any dumping site. The present study provides an environmentally friendly method for sustainable management of toxic and unpleasant tannery solid waste by converting it into biochar, which is a carbon enriched byproduct of organic biomass produced through pyrolysis. The biochar derived from tannery solid waste contained a high percentage of carbon and nitrogen. The $\mathrm{pH}$ of biochar was alkaline (8.6) making it suitable for enhancing nutrient availability as compared to the initial $\mathrm{pH}$ of feedstock which was acidic (4.98). SEM analysis of biochar showed the presence of pores with some deposition of salts while no pores were observed in TSW feedstock. The surface area of biochar was $134.9 \mathrm{~m}^{2} \mathrm{~g}^{-1}$, indicating that it can be used as a soil additive for enhancement of the absorption and adsorption processes as well as providing space for microbial activities. Amount of metals like $\mathrm{Cr}, \mathrm{Fe}$ and $\mathrm{Mg}$ was high in biochar but it is presumed that bioavailability of these essential and non-essential metals to plants is limited. This study suggests the management of tannery solid waste by conversion to biochar and to use it as a soil additive because of properties like alkaline $\mathrm{pH}$, increased surface area due to the presence of pores and essential elements such as $\mathrm{Na}, \mathrm{K}, \mathrm{N}$ and $\mathrm{S}$.
\end{abstract}

Keywords: biochar, pyrolysis, tannery solid waste, waste management

\section{Introduction}

The leather industry in Pakistan is the second export earning industry contributing to 5\% GDP of the country [1] providing bread and butter to more than 500,000 people [2]. For leather manufacturing, raw skins and hides are obtained from the slaughterhouses of buffaloes, cows, sheep and goats.

*e-mail: firdaus.botany@pu.edu.pk
Different types of wastes are produced during the tanning process i.e., solid waste, waste water, and air emissions. This has been considered one of the most highly polluting industries having unfavorable effects on the environment. Solid waste generated by leather industry consists of hairs, chrome shavings, trimmings and buffing dust etc. About $1000 \mathrm{~kg}$ of hides give rise to only $150 \mathrm{~kg}$ of finished leather and about $850 \mathrm{~kg}$ or more of solid waste is produced [3]. At Kasur, there is a treatment plant for effluents from the leather industry, Kasur Tanneries Waste Management 
Agency (KTWMA), located at the Depalpur Road. The solid waste from the industry is being dumped into an open dumping site causing environmental pollution in the nearby area. There is a high risk of food chain contamination in the nearby agricultural lands due to the landfill.

The solid waste is generally treated with conventional and less environment friendly techniques [4]. Some thermo-conversion techniques have also been used to manage the solid waste i.e., direct combustion, liquefaction, gasification, pyrolysis and co-firing. However, the process of pyrolysis could reduce the problem of unpleasant odor and toxicity in TSW by converting it into a value-added product and making it useful. The biochar is a porous and black carbon substance produced through slow pyrolysis of organic biomass at $300-500^{\circ} \mathrm{C}$ [5] under zero or limited oxygen conditions. The properties of biochar depend on the type of raw material, residence time and pyrolysis temperature.

Biochar is a soil conditioner that increases plant growth by preventing nutrient leaching, reducing plant diseases and increasing soil fertility. It increases agricultural diversity in soils that have inadequate amount of organic matter, water, and essential elements i.e., N, P, K [6]. Biochar shows affinities for the holding both inorganic (e.g. heavy metals) and organic (e.g. pharmaceuticals and polyaromatic hydrocarbons (PAHs)) contaminants [7]. Biochar produced through the pyrolysis process ameliorates soil physical, chemical, and biological properties.

This study was aimed at converting the organic tannery solid waste into value added biochar with many times less biomass and its application to soil for improving physical, chemical and biological properties. This study encompasses characterization of tannery solid waste biochar for assessing its positive impact on soil properties.

\section{Material and Methods}

\section{Sample Collection}

Tannery solid waste samples were collected from the solid waste dumping site at the Kasur Tannery Waste Management Agency (KTWMA), at Depalpur Road, Kasur, Pakistan. Sampling of waste was done in a completely randomized block design at the site. After removing $12-15 \mathrm{~cm}$ of the top layer, the samples were taken using a shovel and were transported to the Department of Botany, University of the Punjab, Lahore in plastic sacks. Samples were air dried by spreading on polythene sheets. Impurities such as plastic bags and plant debris were removed. After drying, solid waste samples were stored in airtight bags until they were pyrolyzed in a pyrolysis unit.

\section{Characterization of Tannery Solid Waste}

The $\mathrm{pH}$ and EC of the tannery solid waste were determined by mixing the samples with deionized water using Standard Method of SLC [8]. The moisture content was determined by drying the sample in an oven at $105^{\circ} \mathrm{C}$ for $24 \mathrm{~h}$ [9]. Elements i.e., C, H, N and $\mathrm{S}$ were determined in an elemental analyzer $(\mathrm{GmbH}$, Vario MICRO cube V1.9.4). Nutrient content and heavy metals were determined by acid digestion of tannery solid waste samples on a hot plate using concentrated $\mathrm{HNO}_{3}$ and $\mathrm{HClO}_{4}$ in 2:1 ratio [10]. Metals like $\mathrm{Na}$ and $\mathrm{K}$ were measured by using flame photometer (Corning flame photometer 410- PFP7/C), while $\mathrm{Pb}, \mathrm{Cd}, \mathrm{Cr}, \mathrm{Zn}$, $\mathrm{Mg}, \mathrm{Ni}, \mathrm{Fe}$, and $\mathrm{Cu}$ content was determined using a flame atomic absorption spectrometer (GBC Savaant AA).

The surface appearance of the samples was observed microscopically with a scanning electron microscope (JEOL JSM-6480LV). FTIR spectra provide understanding about the functional groups and aromaticity present on the material. The surface functional groups of the sample were identified by FTIR spectrophotometer (IR Prestige-21 Shimadzu, Japan) in the wavelength range of $400-4000 \mathrm{~cm}^{-1}$ and the results were observed through IR software spectrum. Cation exchange capacity of the samples was determined by the method of Chapman [11].

\section{Biochar Preparation from TSW}

Tannery solid waste biochar was prepared in a locally manufactured charcolator that had two cylindrical containers of stainless steel. The inner small container was used as feedstock assembly, while the outer larger one was used as the fuel chamber. The height of feedstock assembly was $38.5 \mathrm{~cm}$ having a diameter of $21 \mathrm{~cm}$. The small sized container with the feedstock was placed inside the fuel chamber and covered with a lid. A long rod with side blades was used for uniform mixing of feedstock during pyrolysis. Heat was provided to the outer chamber continuously with a biogas connection. The temperature inside the chamber was maintained between $370-450^{\circ} \mathrm{C}$ during pyrolysis using a thermocouple (RKC REX-C900). The biochar was collected in an airtight container for further use.

\section{Characterization of Biochar}

After the pyrolysis process, tannery solid waste biochar (TSWB) was crushed for further analysis. The biochar yield (\%) was calculated with the following formula.

$$
\text { Yield }(\%)=\frac{W_{B}}{W_{F}} \times 100
$$


...where, $\mathrm{W}_{\mathrm{B}}$ is the weight of biochar and $\mathrm{W}_{\mathrm{F}}$ is the weight of feedstock used for the preparation of biochar respectively.

For $\mathrm{pH}$ and EC determination, 1: $20 \mathrm{w} / \mathrm{v}$ ratio of biochar was prepared in deionized water and placed on an orbital shaker for $2 \mathrm{~h}$. The bulk density was determined by adding dried grounded biochar in a $50 \mathrm{ml}$ cylinder and tapped for 1-2 min until it reached a constant volume after which it was weighed. The ash content was determined by using the method of AOAC [9]. The volatile content was determined by placing the biochar in a muffle furnace at $900^{\circ} \mathrm{C}$ for $6 \mathrm{~min}$ [9]. The organic matter was determined at $450^{\circ} \mathrm{C}$ for $24 \mathrm{~h}$ [12].

The percentages of $\mathrm{C}, \mathrm{H}, \mathrm{N}$ and $\mathrm{S}$ were determined as mentioned before. Nutrient content and heavy metals were determined by digesting the biochar with concentrated $\mathrm{HNO}_{3}$ and $\mathrm{HClO}_{4}$ [10]. Heavy metals like $\mathrm{Pb}, \mathrm{Cd}, \mathrm{Cr}, \mathrm{Zn} \mathrm{Ni}, \mathrm{Fe}, \mathrm{Na}, \mathrm{K}, \mathrm{Mg}$, and $\mathrm{Cu}$ were measured by the method described above for the feedstock. The surface structure of biochar was determined by scanning electron microscopy, by laying the biochar sample on a two-sided carbon tape that was attached to an aluminum stick on the electron microscope (JEOL JSM-6480LV).

Cation exchange capacity of biochar was described by Chapman [11]. For FTIR analysis, one mg of the ground biochar was mixed with $200 \mathrm{mg}$ of $\mathrm{KBr}$, and after that the sample was pressed into a pellet using a hydraulic press. The FTIR spectrum of the pellet was observed by wavenumber range from $650 \mathrm{~cm}^{-1}$ $-4000 \mathrm{~cm}^{-1}$. The thermo gravimetric analysis (TGA) of the biochar was determined by using thermal analyzer (SDT Q600, TA instruments) for measuring the thermal stability of the sample. The pore size, pore volume and surface area of TSWB was determined by BrunauerEmmett-Teller (BET) instrument.

\section{Results and Discussion}

\section{Characteristics of Feedstock}

Physicochemical characterization of tannery solid waste, as the feedstock, is shown in Table 1. The $\mathrm{pH}$ and EC value of TSW was 4.98 and $3.21 \mathrm{~d} \mathrm{Scm}^{-1}$ respectively. The acidic $\mathrm{pH}$ of TSW might be due to salts and acids (sulphuric acids and formic acid etc.) used in leather processing. Conductivity was high due to the presence of salts and inorganic substances used in the tanning process. Paul et al. [13] studied the potential of tannery solid waste for its usage as poultry feed and reported that $\mathrm{pH}$ of TSW biomass was 4.1. Arslan [14] observed the acidic $\mathrm{pH}$ (4.55) of fruit and vegetable wastes and reported that the acidic $\mathrm{pH}$ might be due to fermentation and hydrolytic processes which were taking place in storage container. Elemental analysis indicated that $\mathrm{C}$ and $\mathrm{N}$ content was higher as compared to $\mathrm{H}$ and $\mathrm{S}$. The reason behind the high $\mathrm{N}$ content is the presence of hairs and other proteins in the
Table 1. A comparison of physicochemical characteristics of tannery solid waste and its derived biochar.

\begin{tabular}{|c|c|c|c|}
\hline Sr No. & $\begin{array}{l}\text { Physicochemical } \\
\text { parameters }\end{array}$ & $\begin{array}{c}\text { Tannery } \\
\text { solid waste }\end{array}$ & $\begin{array}{l}\text { Tannery solid } \\
\text { waste biochar }\end{array}$ \\
\hline 1 & Yield (\%) & -- & 41 \\
\hline 2 & $\mathrm{pH}(1: 20)$ & 4.98 & 8.6 \\
\hline 3 & $\mathrm{EC}\left(\mathrm{dS} \mathrm{cm}{ }^{-1}\right)$ & 3.21 & 4.71 \\
\hline 4 & OM (\%) & -- & 14 \\
\hline 5 & $\mathrm{BD}\left(\mathrm{g} \mathrm{cm}^{-3}\right)$ & -- & 0.66 \\
\hline 6 & $\mathrm{VC}(\%)$ & -- & 62 \\
\hline 7 & $\mathrm{AC}(\%)$ & -- & 73 \\
\hline 8 & MC (\%) & 23 & 6 \\
\hline 9 & $\operatorname{CEC}\left(\mathrm{cmol}_{\mathrm{c}} \mathrm{kg}^{-1}\right)$ & 14 & 19 \\
\hline 10 & $\mathrm{C}(\%)$ & 32.19 & 41.23 \\
\hline 11 & $\mathrm{H}(\%)$ & 3.98 & 2.28 \\
\hline 12 & $\mathrm{~N}(\%)$ & 8.05 & 6.56 \\
\hline 13 & S (\%) & 2.12 & 1.42 \\
\hline 14 & $\mathrm{C} / \mathrm{N}$ ratio & 3.99 & 6.28 \\
\hline 15 & $\mathrm{C} / \mathrm{H}$ ratio & 8.08 & 18.08 \\
\hline
\end{tabular}

EC: electrical conductivity, OM: organic matter, BD: bulk density, VC: volatile content, AC: ash content, MC: moisture content, CEC: cation exchange capacity, C: carbon, H: hydrogen, N: nitrogen, S: Sulphur

hides and associated animal flesh in the TSW. Nitrogen supplies nutrients to soil for plant growth. Carlos et al. [15] reported that leather tannery waste has high sulphur and nitrogen content and it might be due to the presence of various natural proteins and among them the most valuable protein is the collagen. Katiyar et al. [16] physico-chemically characterized thirteen samples of municipal solid waste and reported average values of elements were C: $26.6 \%, \mathrm{~N}: 1.1 \%, \mathrm{H}: 5.9 \%$. and S: $0.98 \%$.

The TSW contained the heavy metals $\mathrm{Cr}, \mathrm{Pb}, \mathrm{Cd}$, $\mathrm{Zn}, \mathrm{Cu}, \mathrm{Ni}$ and $\mathrm{Fe}$ along with $\mathrm{Na}, \mathrm{K}$ and $\mathrm{Mg}, \mathrm{Cr}$ being the highest as compared to all others. Among the essential metals, $\mathrm{Mg}$ was the highest followed by $\mathrm{Fe}$ and $\mathrm{Zn}$ respectively (Fig. 1). The high metal content in TSW might be due to chemicals used in beamhouse treatment and tanning process. The high level of $\mathrm{Cr}$ in TSW is due to pigments, dyes, tanning salts and preservatives. This is in line with Koki and Jimoh [17] who reported high concentration of $\mathrm{Cr}, \mathrm{Zn}, \mathrm{Cu}$, and $\mathrm{Pb}$ in TSW due to the chrome tanning process and bioaccumulation of fumes of burnt TSW.

The scanning electron microscopic (SEM) image of TSW showed salt particles gathered on the surfaces of material as shown in Fig. 2. The white particles appeared dense and the image displayed no pores on the surface. Similar results have been observed by Karim et 


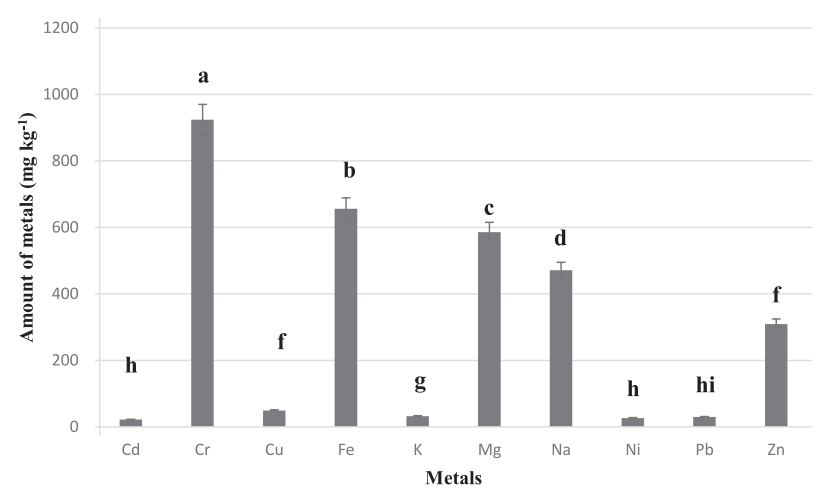

Fig. 1. Amount of different metals present in tannery solid waste (TSW). Bars represent SD of three replicates. Different letters indicate significant differences among treatments at $\mathrm{p} \leq 0.05$.

al. in the tannery solid waste [18]. They reported that $\mathrm{Cr}$ atoms were bound with $\mathrm{O}, \mathrm{Si}, \mathrm{S}, \mathrm{C}, \mathrm{Ca}, \mathrm{Al}$, and $\mathrm{Fe}$.

Fourier transform infrared spectroscopy (FTIR) spectra of the TSW are shown in Fig 3. The spectra were analyzed on the basis of previously published data. In this study, important peaks observed through FTIR spectra are as follows: $\mathrm{O}-\mathrm{H}$ stretching at $3390.86 \mathrm{~cm}^{-1}$ [19] showed the presence of more active sites on the surface of the biochar, an amine or Amide $\mathrm{N}-\mathrm{H}$ bond formed at wavelength $3313.71 \mathrm{~cm}^{-1}$, Alkane $\mathrm{C}-\mathrm{H}$ stretching formed at wavelength $2945.30 \mathrm{~cm}^{-1}$ [19], an amide II band at $1543.05 \mathrm{~cm}^{-1}$ shows the presence of various amino group, little proteins, carbohydrates and nucleic acid, $\mathrm{CH}_{3}$ bending vibration for lipids and protein at $1456.28 \mathrm{~cm}^{-1}$, the band at $1400.32 \mathrm{~cm}^{-1}$ was due to C-O stretching [20], an amide III and asymmetric phosphodiester stretching at $1236.37 \mathrm{~cm}^{-1}$ [21], phosphate band appeared at $1082.07 \mathrm{~cm}^{-1}$ and $\mathrm{C}-\mathrm{O}$ stretching was observed at $1039.63 \mathrm{~cm}^{-1}$ [22]. Having the source of material from animals, important protein and fat functional groups are evident.

\section{Characteristics of the Biochar}

The yield of biochar was $41 \%$ at a pyrolysis temperature of $370-450^{\circ} \mathrm{C}$ (Table 1). Hina et al. [23] reported that biochar of pine and eucalyptus barks with diluted and undiluted tannery slurry yield was $29 \%$ and $32 \%$ respectively. High yield of biochar was due to slow pyrolysis temperature, type of feedstock and residence time. The decrease in the yield of biochar compared to feedstock was might be due to devolatilisation of the wastes to produce gases and volatiles which led to the decrease in weight and leaving the the non-volatile fraction in the form of biochar. The $\mathrm{pH}$ and $\mathrm{EC}$ value of tannery solid waste biochar (TSWB) was 8.6 and $4.71 \mathrm{~d} \mathrm{Scm}^{-1}$ respectively. The $\mathrm{pH}$ of tannery waste soil biochar ranged from 9.97-10.01 [24]. The alkaline nature of biochar was also illustrated by Spokas et al. [25] and the increase in EC is primarily due to the salts present in the feedstock and their accumulation during pyrolysis process.

In the present study, the bulk density of biochar was $0.66 \mathrm{gcm}^{-3}$ and the ash content was $73 \%$. Bulk density depends on the pyrolysis temperature, residence time and feedstock type. In the current study, bulk density is low due to the presence of pores that can hold water, nutrients or air. Randolph et al. [26] showed that the bulk density of biochar prepared from plant residue and wood chips was $0.2 \mathrm{~g} \mathrm{~mL}^{-1}$ and the increase in bulk density was due to the high lignin content of wood. Głąb et al. [27] reported that as the amount of biochar increased, bulk density starts to decrease. Biochar having low bulk density has the potential to improve the characteristics of compact soil. The results for ash content conform to Figueredo et al. [28] who observed that sewage sludge biochar contained $65.81 \%$ ash in biochar prepared at $500^{\circ} \mathrm{C}$. This seemed to be due to the slow release of $\mathrm{C}, \mathrm{H}, \mathrm{N}$, and $\mathrm{O}$ during the pyrolysis process. Ash content was increased with increase in
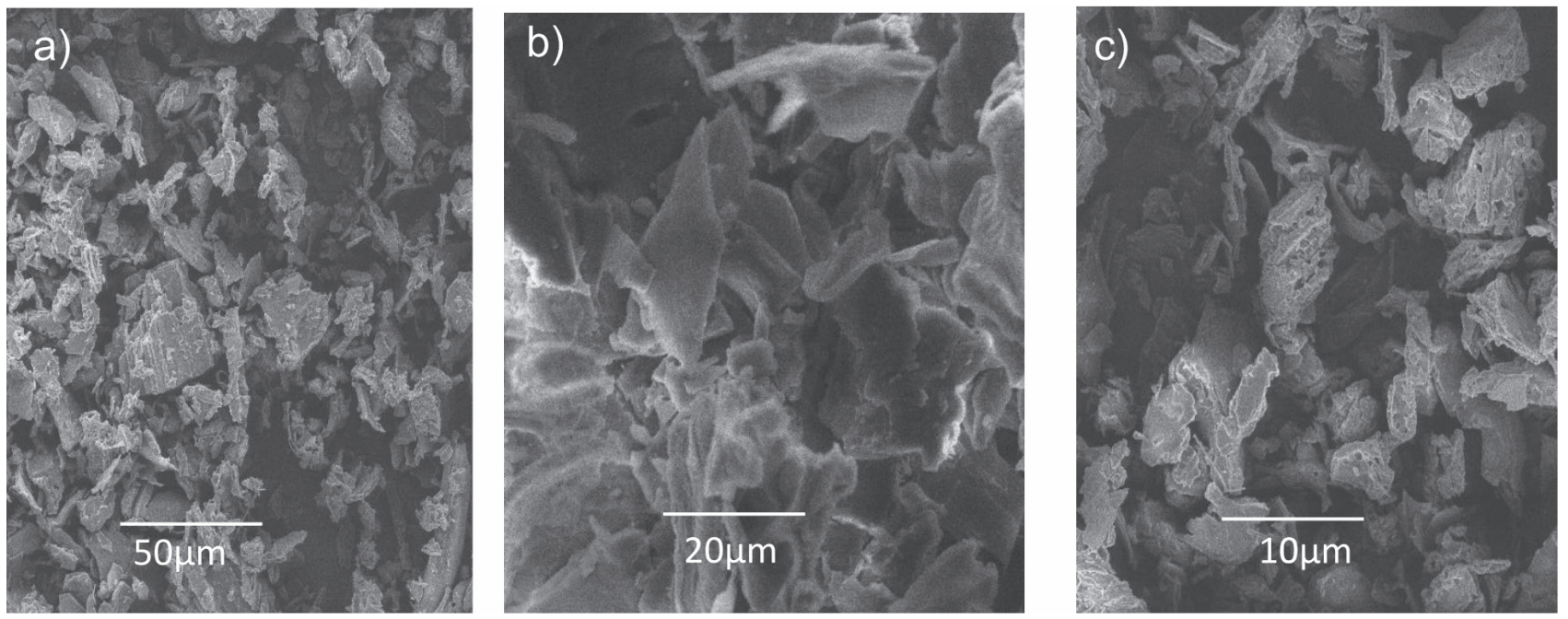

Fig. 2. Scanning electron microscopic (SEM) images of tannery solid waste (TSW) showing salt particles on the surface with no pores a) $430 \mathrm{X}, \mathrm{B}) 1500 \mathrm{X}, \mathrm{C}) 2500 \mathrm{X}$. 


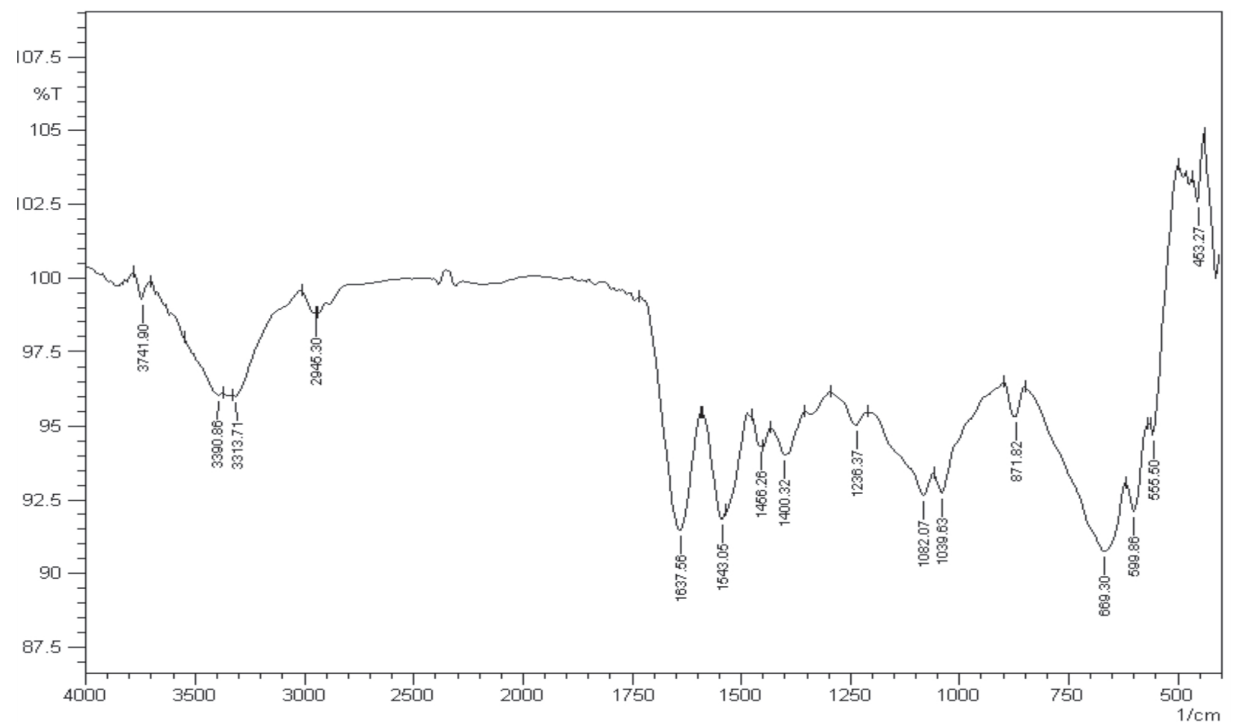

Fig. 3. Fourier transform infrared spectroscopy (FTIR) of tannery solid waste in the wavelength range of $400-4000 \mathrm{~cm}^{-1}$.

pyrolysis temperature. Kearns et al [29] reported high ash content of biochar prepared from rice straw (48.4\%) compared to bamboo $(5.1 \%)$ and wood chip biochar $(3.0 \%)$

In the current investigation, the volatile matter content was 62\%. Agrafioti et al. [30] observed 73.3\% volatile matter in sewage sludge. The pore formation is due to the loss of volatile matter as reported by Fu et al. [31]. As the TSWB contained high volatile content, pores were formed in it (Fig. 5). Primarily, volatiles consist of $\mathrm{CO}_{2}, \mathrm{CO}, \mathrm{CH}_{4}, \mathrm{~N}_{2}, \mathrm{H}_{2}$ and gaseous carbohydrate. The high volatile content of TSWB might be recognized due to higher carbon mineralization. Volatile content and yield of biochar decreased with increase in pyrolysis temperature. The higher value of volatile content might be due to presence of certain components which resist pyrolytic decomposition. Spokas [32] reported that volatile content of biochar above $80 \%$ have no carbon

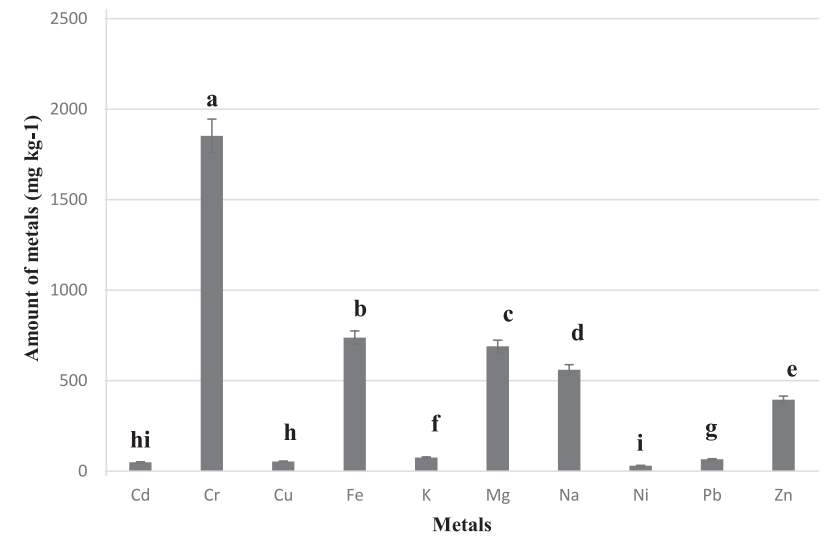

Fig. 4. Amount of different metals present in the tannery solid waste biochar (TSWB). Bars represent SD of three replicates. Different letters indicate significant differences among treatments at $\mathrm{p} \leq 0.05$. sequestration property while, volatile content of biochar below $80 \%$ with organic carbon to nitrogen ratio below 0.4 indicate high carbon sequestration potential.

Carbon in the biochar was $41.23 \%$ whereas $\mathrm{N}, \mathrm{H}$ and $\mathrm{S}$ content reduced significantly as compared to feedstock, due to the process of carbonization. The decrease in $\mathrm{N}, \mathrm{H}$, and $\mathrm{S}$ might be due to volatilization of elements from the surface of the material, whereas other elements become concentrated in the remaining biochar. Hina et al. [23] worked on different feedstocks and showed similar range of carbon content for tannery waste soil biochar. Carbon content increased with the increase in pyrolysis temperature might be due to the release of volatile content which led to the enrichment of carbon content in biochar. The loss of $\mathrm{H}, \mathrm{S}$ and $\mathrm{N}$ is due to the splitting of bonds during the pyrolysis of TSW. Shenbagavalli and Mahimairaja [33] reported that $\mathrm{C}$ stored in biochar is not lost into the atmosphere but remains stable for long periods of time due to the formation of pyrogenic carbon. Thus, biochar formation sequesters the $\mathrm{C}$ present in the feedstock. Yakout [34] illustrated 45-65 \% carbon and 1.1-1.7 nitrogen in biochar derived from rice straw. Hence, the addition of biochar enhances soil fertility by increasing soil $\mathrm{N}$ and $\mathrm{C}$ content as well as sequester greenhouse gases [35].

In TSWB, a slight increase in metal concentration was observed as shown in Fig 4. Through the process of pyrolysis, organic contaminants are degraded but heavy metal content is enriched. The present result showed high concentration of $\mathrm{Cr}$ followed by $\mathrm{Fe}$ and $\mathrm{Mg}$. After the process of pyrolysis, no significant increase was observed in $\mathrm{Cd}, \mathrm{Cu}, \mathrm{Ni}$ and $\mathrm{Pb}$. The increase in metal content might be due to reduction in the biomass of tannery solid waste during pyrolysis process and their concentration in the prepared biochar. Liu et al. [36] worked on sewage sludge biochar and showed that $\mathrm{Cu}, \mathrm{Pb}, \mathrm{Zn}, \mathrm{Cd}$, and $\mathrm{Cr}$ concentrations were considerably higher in biochar than the raw sample, 

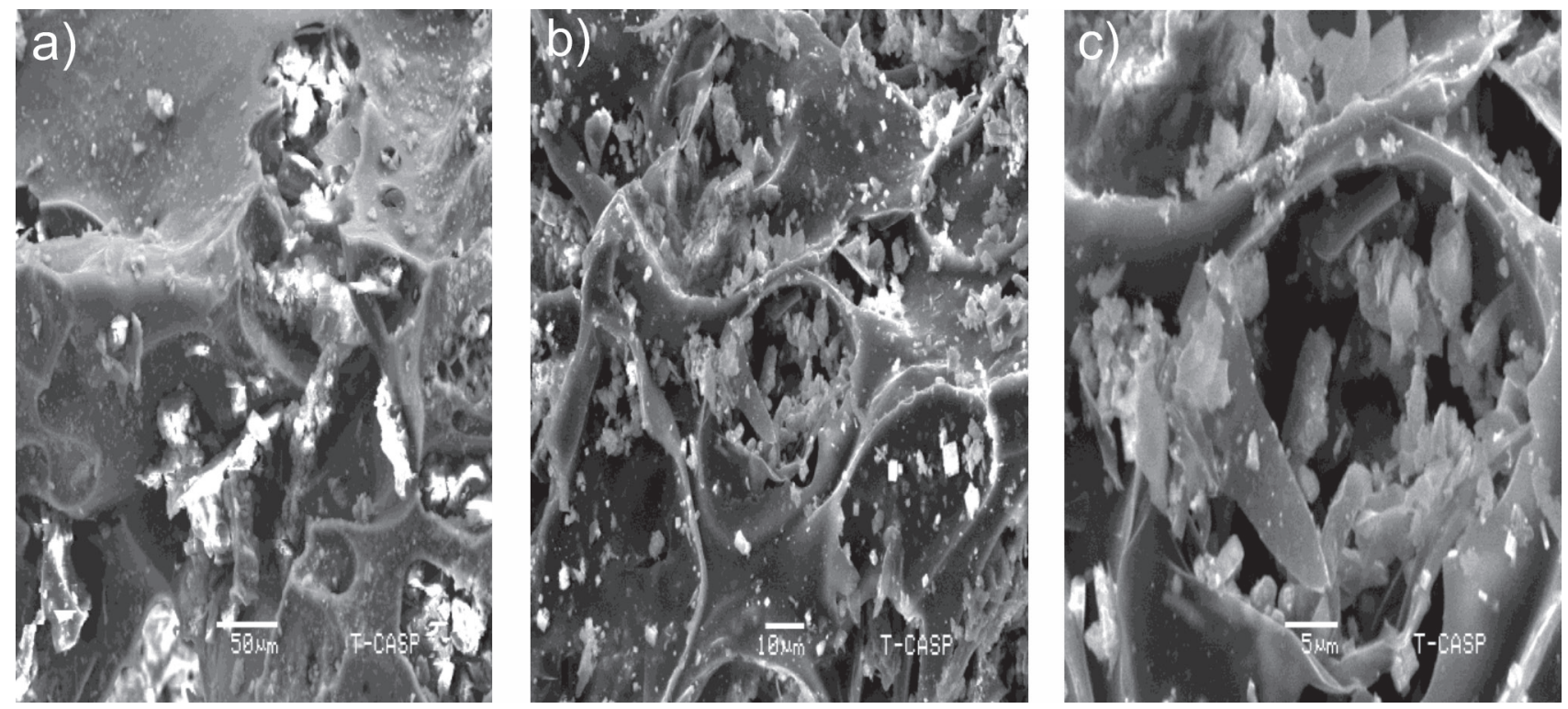

Fig. 5. Scanning electron microscopic images of tannery solid waste biochar (TSWB) showing pores of varying size and having scattered salt particles on the surface a) $430 \mathrm{X}$, b) 1000X, c) $3500 \mathrm{X}$.

but bioavailability of these heavy metals to plants was lower than those of air-dried sewage sludge. Further experiments are required to check the bioavailability of toxic metals after addition of TSW biochar to the soil. Chen et al. [37] reported high level of $\mathrm{P}, \mathrm{Ca}, \mathrm{K}, \mathrm{Fe}$ and $\mathrm{Mg}$, while lower content of $\mathrm{Na}, \mathrm{Cu}$ and $\mathrm{Cr}$ was observed in municipal sewage sludge.

In general, the cation exchange capacity (CEC) is a measure of soil fertility. It is the ability of sample to absorb nutrients which are essential for plant growth. In this study, CEC of TSWB biochar was $19 \mathrm{cmol} / \mathrm{kg}$. The increase in CEC seems to be due to the oxidation of functional groups present on its surface and surface area of the biochar [38]. Munera et al. [39] reported high CEC of cacao shell biochar (59.1) compared to corncob biochar (6.0). The reason for high CEC is the presence of large number of micropores. Takaya et al. [40] finding showed that greenhouse and oak waste derived biochar had high CEC compared to municipal waste biochar. It might be because of presence of lower ash contents and high content of lignocellulosic.

To observe the quality, porosity, distribution and pore size, scanning electron microscopy of biochar was done. The SEM image of TSWB showed that it was a moulded skeleton with pores of different sizes having irregular surface (Fig. 5). A high content of mineral deposition was observed on the surface. The pores in the biochar are formed by the loss of volatile

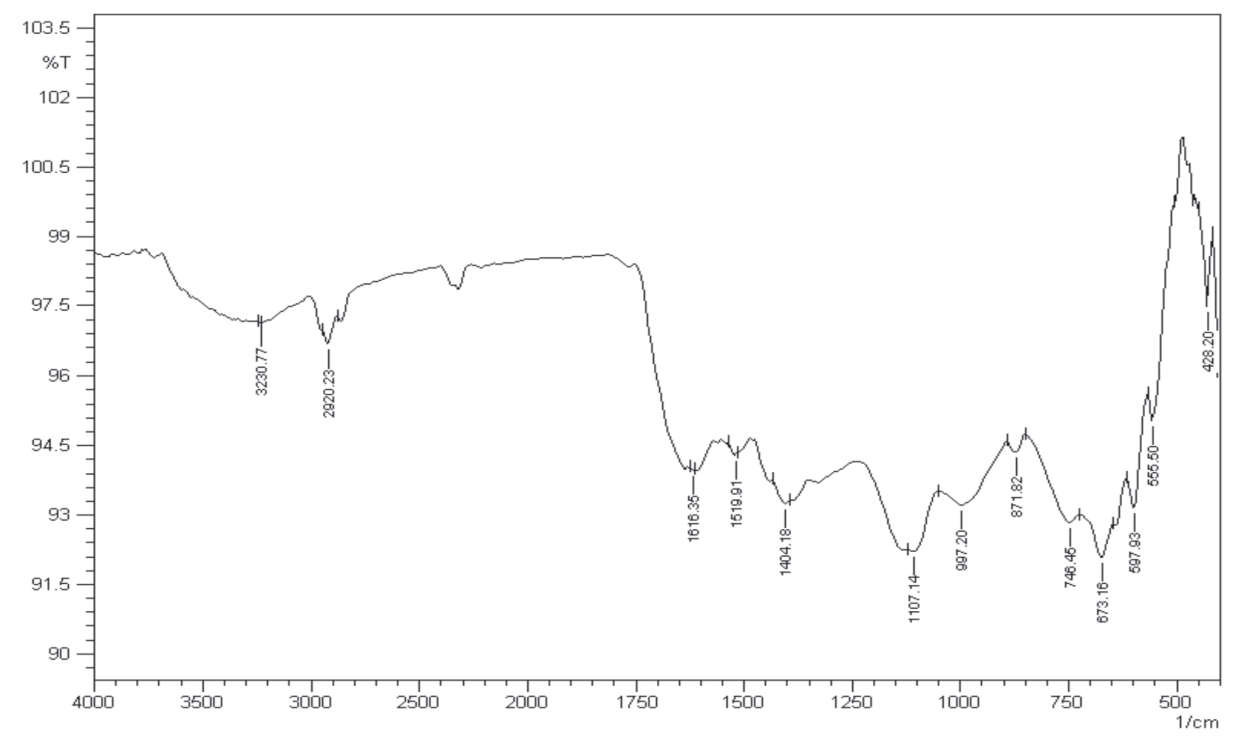

Fig. 6. Fourier transform infrared spectroscopy (FTIR) of tannery solid waste biochar in the wavelength range of $400-4000 \mathrm{~cm}^{-1}$. 


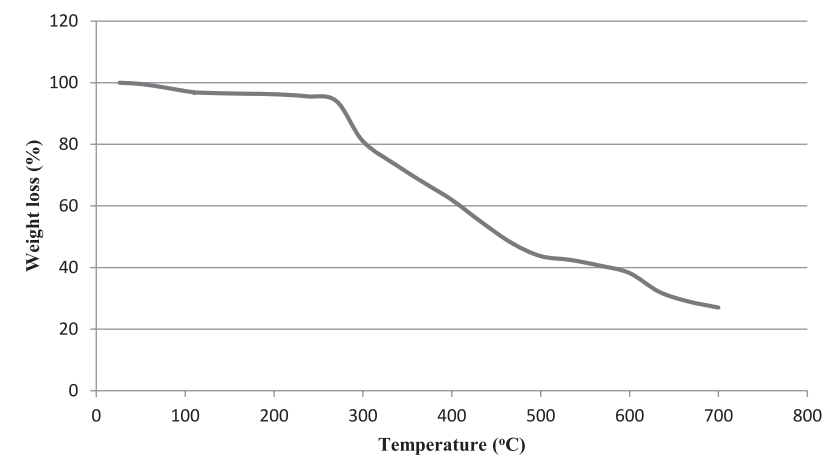

Fig. 7. Thermogravimetric (TGA) curve of tannery solid waste biochar (TSWB) showing percentage weight loss with increasing temperature.

matter during pyrolysis [31]. Similar results have been obtained by Mary et al. [41], who worked on cauliflower leaf, orange peel, and pea pod wastes. The SEM image of OP waste showed uneven surface and broken edges with some mineral deposition on the surface.

Fourier transform infrared spectroscopy (FTIR) spectra of the biochar is given in Fig. 6. FTIR peaks provide information about the functional groups and aromaticity of samples. The biochar peaks obtained were: The $\mathrm{O}-\mathrm{H}$ symmetric stretching at $3230 \mathrm{~cm}^{-1}$ showed the presence of alcohol and carboxylic acid [19]. An aliphatic asymmetric and symmetric stretching of $\mathrm{C}-\mathrm{H}$ bond in $\mathrm{CH}_{2}$ and $\mathrm{CH}_{3}$ was observed at wavelength $2920.23 \mathrm{~cm}^{-1}$ [42]. The peak formed at $1616.35 \mathrm{~cm}^{-1}$ assigned to carboxyl $\mathrm{C}=\mathrm{N}$ stretch shows that amine groups stick to the surface of biochar [43]. The peak at $1519.91 \mathrm{~cm}^{-1}$ wavelength attributed to aromatic $\mathrm{C}=\mathrm{C}$ bonds indicates the presence of unsaturated aryl substituent alkenes. The peak at $1404.18 \mathrm{~cm}^{-1}$ assigned to $\mathrm{C}-\mathrm{H}$ bond confirm the aliphatic nature of biochar [44]. The peaks at $1107 \mathrm{~cm}^{-1}$ formed due to $\mathrm{C}-\mathrm{O}$ and $\mathrm{C}-\mathrm{C}$ ring which indicates the presence of alcohol and esters [45]. The remaining peaks were $997.20 \mathrm{~cm}^{-1}$ $\mathrm{C}-\mathrm{H}$ in plane bending [46] $871.82 \mathrm{~cm}^{-1}$ amines $\mathrm{H}-\mathrm{N}$, $746.45 \mathrm{~cm}^{-1}$ alkyl halide $\mathrm{C}-\mathrm{Cl}, 673.45 \mathrm{~cm}^{-1}$ alkynes bend and $555.50 \mathrm{~cm}^{-1}$ alkyl halide C-Br.
The Brunauer-Emmett-Teller (BET) method proposes to distinguish the physical adsorption of gas molecules for measuring surface area [47]. In this study, BET surface area of biochar was $134.9 \mathrm{~m}^{2} \mathrm{~g}^{-1}$, which indicates the presence of fewer tiny pores. Suliman et al. [48] observed that the maximum surface area was in the range of $145-500 \mathrm{~m}^{2} \mathrm{~g}^{-1}$ from different biochars prepared at $400-600^{\circ} \mathrm{C}$. In this study, surface pore volume and diameter were $10.24 \mathrm{~cm}^{3} \mathrm{~g}^{-1}$ and $35.98 \mathrm{~A}^{\circ}$ respectively, which shows that the surface pores have the ability to hold the nutrients and microbes. The presence of pores in biochar provide ideal environment for microbes to increase their population size and colonies.

Thermogravimetric analysis (TGA) is used to measure the stability of a sample over time with change in temperature (Fig. 7) for TSWB. The first weight loss was $0.5 \%$ at $50^{\circ} \mathrm{C}$ while the second weight loss was $18 \%$ from $100-300^{\circ} \mathrm{C}$. The third weight loss was about $62 \%$ from $300-600^{\circ} \mathrm{C}$. About $24 \%$ sample remained non-combustible after $600^{\circ} \mathrm{C}$. Gil et al. [49] reported that the decrease in weight of biochar is due to moisture evaporation, devolatilization and char combustion. This is why, the biochar obtained is light weighted and fluffy in appearance. Pyrolysis has an important impact in the reduction of toxic biomass of TSW.

When the TSWB was added to the soil in terms of tons per hectare $\left(t \mathrm{ha}^{-1}\right)$ unit, the soil characteristics became more desirable (Table 2). The conductivity value increased showing availability of soluble salts. Organic matter content and cation exchange capacity of the soil were greatly improved which are very important for improving growth of the plants. The metal content increased with increase in the amount of TSWB concentration in soil (Fig. 8). World health organization (WHO), food and agricultural organization (FAO) and Dutch standard has set the permissible limit of metals in soil. Instead of $\mathrm{Cr}$ and $\mathrm{Pb}$, all remaining metals were in the permissible limit in the soil. Further experiments are required to investigate the beneficial impacts of the biochar amendment. However, ornamental plants, oilyielding or energy crops are recommended to be grown to minimize the entry of heavy metals in the food chain.

Table 2. A comparison of some physicochemical characteristics of soil only and soil after addition of tannery solid waste biochar (TSWB).

\begin{tabular}{|c|c|c|c|c|c|c|c|c|}
\hline \multirow{2}{*}{ Sr No. } & \multirow{2}{*}{ Physicochemical parameters } & \multirow{2}{*}{ Soil only } & \multicolumn{5}{|c|}{ TSWB-Soil amendments $\left(\mathrm{t}\right.$ ha $\left.{ }^{-1}\right)$} \\
\cline { 5 - 10 } & & & 5 & 10 & 15 & 20 & 25 & 30 \\
\hline 1 & $\mathrm{pH}$ & 6.72 & 7.19 & 7.32 & 7.49 & 7.74 & 8.1 & 8.23 \\
\hline 2 & $\mathrm{EC}\left(\mathrm{dS} \mathrm{cm}^{-1}\right)$ & 0.07 & 0.1 & 0.14 & 0.17 & 0.2 & 0.22 & 0.25 \\
\hline 3 & $\mathrm{NaCl}(\%)$ & 4.2 & 19.2 & 35.7 & 56.3 & 70.3 & 84.9 & 102.3 \\
\hline 4 & $\mathrm{OM} \mathrm{( \% )}$ & 3.2 & 3.9 & 4.5 & 5.0 & 5.4 & 5.9 & 6.5 \\
\hline 5 & $\mathrm{BD}\left(\mathrm{g} \mathrm{cm}^{-3}\right)$ & 1.15 & 1.11 & 1.06 & 0.98 & 0.92 & 0.86 & 0.82 \\
\hline 6 & $\mathrm{CEC}\left(\mathrm{cmol}_{\mathrm{c}} \mathrm{kg}^{-1}\right)$ & 9 & 10.1 & 10.9 & 11.6 & 12.1 & 12.6 & 13.2 \\
\hline
\end{tabular}

EC: electrical conductivity, OM: organic matter, BD: bulk density, CEC: cation exchange capacity 


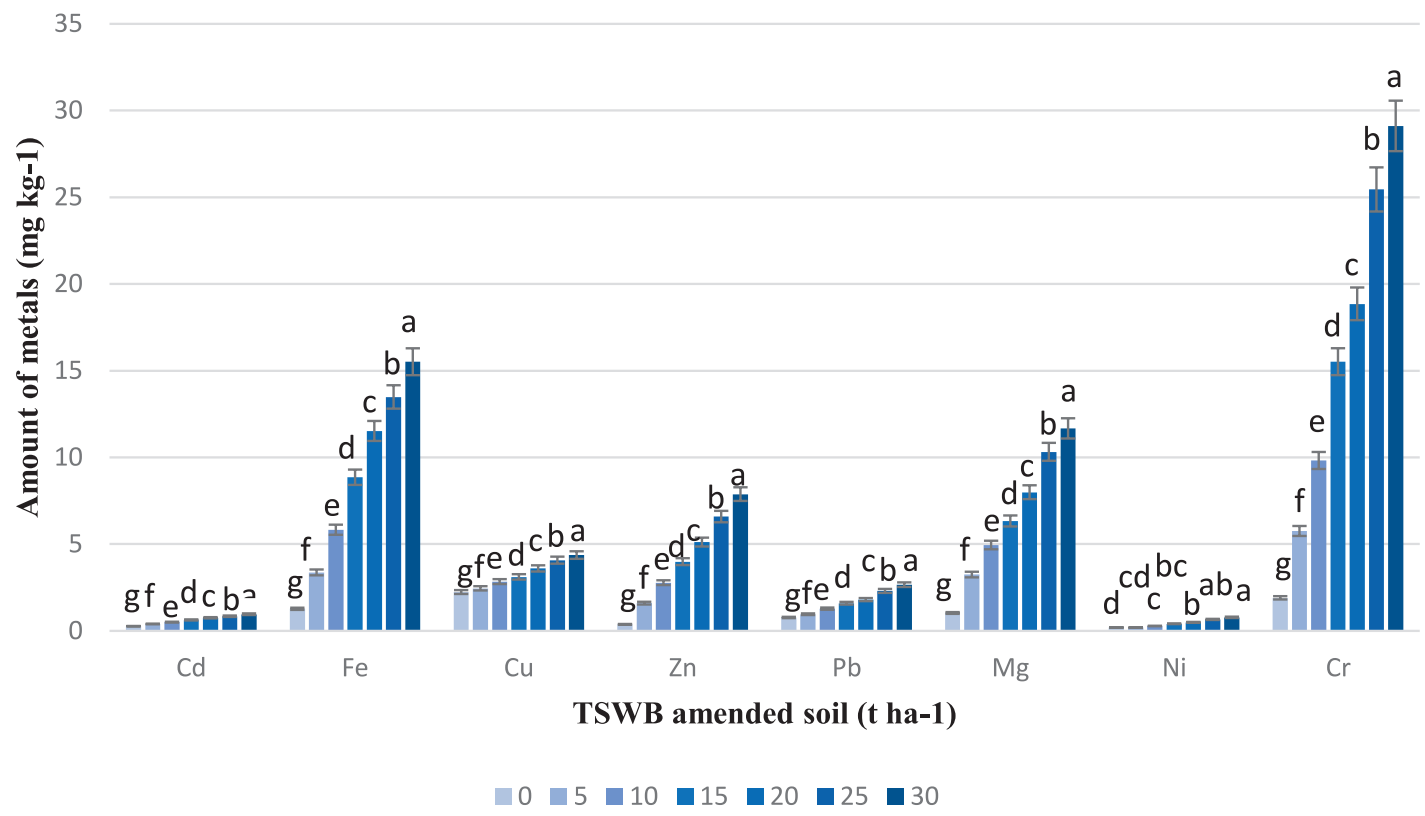

Fig. 8. Amount of different metals present in the tannery solid waste biochar (TSWB) amended soil. Bars represent SD of three replicates. Different letters indicate significant differences among treatments at $p \leq 0.05$.

\section{Conclusion}

Tannery solid waste dumping in a landfill or open dumping site is not a safe way of disposal. The pyrolysis process permits to utilize biochar of this feedstock as a soil conditioner by reducing its huge volume and improving soil properties. A high surface area and CEC of biochar increases the water holding and nutrient retention capacity of soil, if used as a soil additive. Tannery solid waste biochar is a rich source of micronutrients and macronutrients. Although different heavy metals in biochar are concentrated, they are not presumably bio-available to plants for uptake. However, further research is required for checking the implications of using TSWB as a soil additive.

\section{Acknowledgements}

The authors thank Kasur Tannery Waste Management Agency (KTWMA), Depalupur road, Kasur for providing tannery solid waste samples.

\section{Conflict of Interest}

The authors declare no conflict of interest.

\section{References}

1. GHAFOOR A., ASLAM M., RASOOL S. Determinants of leather goods exports: A case of Pakistan. Journal of Business and Economics, 4, 256, 2012.
2. SIDDIQUI A., UROOS A., NADEEM F. Sectoral competitiveness and value chain analysis: leather Gloves value chain analysis in Pakistan. Trade development authority of Pakistan, 2016.

3. RAMAMURTHY G., RAMALINGAM B., KATHEEM M.F., SASTRY T.P., INBASEKARAN S., THANVEER V., JAYARAMACHANDRAN S., DAS S.K., MANDAL A.B. Total Elimination of Polluting Chrome Shavings, Chrome, and Dye Exhaust Liquors of Tannery by a Method Using Keratin Hydrolysate. ACS Sustainable Chemistry \& Engineering, 3, 1348, 2015.

4. SINGH R., SETIAWAN A.D. Biomass energy policies and strategies: harvesting potential in India and Indonesia. Renew. Renewable and Sustainable Energy Reviews, 22, 332, 2013.

5. MALIŃSKA K. Biochar-a response to current environmental issues. Environment Protection Engineering, 15 (4), 387, 2012.

6. IGALAVITHANA A.D., OK Y.S., USMAN A.R.A., ALWABEL M.I., OLESZCZUK P., LEE S.S. The effects of biochar amendment on soil fertility. Agricultural and environmental applications of biochar: Advances and barriers. Soil Science Society of American Journal, 63, 123, 2016.

7. BAIR D.A., MUKOME F.N.D., POPOVA I.E., OGUNYOKU T.A., JEFFERSON A., WANG D., HAFNER S.C., YOUNG T.M., PARIKH S.J. Sorption of pharmaceuticals, heavy metals, and herbicides to biochar in the presence of biosolids. Journal of Environmental Quality, 45, 1998, 2016.

8. SOCIETY OF LEATHER TECHNOLOGISTS AND CHEMISTS (SLC). Official Methods of Analysis, Northampton, UK, 1996.

9. AOAC. Official methods of analysis. Association of Official Analytical Chemists International, Maryland, USA, 2000.

10. CLESSERI L.S., GREENBERG A.E., EATON A.D. Standard methods for the examination of water and waste 
water $\left(20^{\text {th }}\right.$ Ed). American Public Health Association, U.S.A, 215, 1998.

11. CHAPMAN H.D. Cation-exchange capacity 1. Methods of soil analysis. Part 2. Chemical and microbiological properties (Methods of Soil Anal.), 891, 1965.

12. ASTM D4719/87. AMERICAN SOCIETY FOR TESTING OF MATERIALS. Standard Test Method for Pressure meter Testing in Soils. Annual Book of ASTM Standards, New York, 04, 1987.

13. PAUL H., ANTUNES A.P.M., COVINGTON A.D., EVANS P., PHILLIPS P.S. Towards zero solid waste: Utilising tannery waste as a protein source for poultry feed. Journal of Solid Waste Technology and Management, ISSN 1091-8043, 2013.

14. ARSLAN K. Use of a novel bioreactor configuration in the form of high solid digestion for municipal organic wastes at pilot scale. Makalenizi yükleyebilmek için lütfen İngilizce dilini seçiniz!!! EJENS, 2 (1), 120, 2017.

15. CARLOS F.N., MÉNDEZ-VELÁSQUEZ J.A., SIERRAVARGAS F.E. Energetic improvement of tanned leather solid wastes by thermal treatment. Ingeniería y Desarrollo, 33, 1, 2015.

16. KATIYAR R.B., SURESH S., SHARMA A.K. Characterization of municipal solid waste generated by the city of Bhopal, India. International Journal of ChemTech Research, 5 (2), 623, 2013.

17. KOKI I.B., JIMOH W.L.O. Assessment of heavy metals in tannery solid waste from Challawa Industrial Estate, Kano State, Nigeria. International Journal of Research in Environmental, 2, 33, 2015.

18. KARIM M.R., MANSHOVEN S., ISLAM M.R., GASCON J.A., IBARRA M., DIELS L., RAHMAN M.M. Assessment of an urban contaminated site from tannery industries in Dhaka city, Bangladesh. Journal of Hazardous, Toxic and Radioactive Waste, 17, 52, 2012.

19. ANJOS O., CAMPOS M.G., RUIZ P.C., ANTUNES P. Application of FTIR-ATR spectroscopy to the quantification of sugar in honey. Food chemistry, 169, 218, 2015.

20. KUMAR K.M., MANDAL B.K., TAMMINA S.K. Green synthesis of nano platinum using naturally occurring polyphenols. RSC Advances, 3 (12), 4033, 2013.

21. VERDONCK M., DENAYER A., DELVAUX B., GARAUD S., DE-WIND R., DESMEDT C., SOTIRIOU C., WILlARD-GALlO K., GOORMAGHTIGH E. Characterization of human breast cancer tissues by infrared imaging. Analyst, 141, 606, 2016.

22. LUCASSEN G.W., VAN-VEEN G.N., JANSEN J.A. Band analysis of hydrated human skin stratum corneum attenuated total reflectance Fourier transform infrared spectra In Vivo. Journal of Biomedical Optics, 3, 267, 1998.

23. HINA K., BISHOP P., ARBESTAIN M.C., CALVELOPEREIRA R., MACIÁ-AGULLÓ J.A., HINDMARSH J., HANLY J.A., MACIAS F., HEDLEY M.J. Producing biochars with enhanced surface activity through alkaline pretreatment of feedstocks. Journal of Soil Research, 48, 606, 2010.

24. HERATH I., IQBAL M.C.M., AL-WABEL M.I., ABDULJABBAR A., AHMAD M., USMAN A.R., OK Y.S., VITHANAGE M. Bioenergy-derived waste biochar for reducing mobility, bioavailability, and phytotoxicity of chromium in anthropized tannery soil. Journal of Soils and Sediments, 17, 731, 2017.

25. SPOKAS KA., CANTRELL K.B., NOVAK J.M., ARCHER D.W., IPPOLITO J.A., COLLINS H.P.,
BOATENG A.A., LIMA I.M., LAMB M.C., MCALOON A.J., LENTZ R.D., NICHOLS K.A. Biochar: a synthesis of its agronomic impact beyond carbon sequestration. Journal of Environmental Quality, 41, 973, 2012.

26. RANDOLPH P., BANSODE R.R., HASSAN O.A., REHRAH D., RAVELLA R., REDDY M.R., WATTS D.W., NOVAK J.M., AHMEDNA M. Effect of biochars produced from solid organic municipal waste on soil quality parameters. Journal of Environmental Management, 192, 271, 2017.

27. GŁĄB T., PALMOWSKA J., ZALESKI T., GONDEK K. Effect of biochar application on soil hydrological properties and physical quality of sandy soil. Geoderma, 281, 11, 2016.

28. FIGUEREDO N.A.D., COSTA L.M.D., MELO L.C.A., SIEBENEICHLERD E.A., TRONTO J. Characterization of biochars from different sources and evaluation of release of nutrients and contaminants. Revista Ciência Agronômica, 48, 3, 2017.

29. KEARNS J.P., WELLBORN L.S., SUMMERS R.S., KNAPPE D.R.U. 2, 4-D adsorption to biochars: Effect of preparation conditions on equilibrium adsorption capacity and comparison with commercial activated carbon literature data. Water research, 62, 20, 2014.

30. AGRAFIOTI E., BOURAS G., KALDERIS D., DIAMADOPOULOS E. Biochar production by sewage sludge pyrolysis. Journal of Analytical and Applied Pyrolysis, 101, 72, 2013.

31. FU P., HU S., XIANG J., SUN L., YANG T., ZHANG A., WANG Y., CHEN G. Effects of pyrolysis temperature on characteristics of porosity in biomass chars. International Journal of Energy and Environmental Engineering, 1, 109, 2009.

32. SPOKAS K.A. Review of the stability of biochar in soils: predictability of O:C molar ratios. Carbon Management, 1, 289, 2010.

33. SHENBAGAVALLI S., MAHIMAIRAJA S. Characterization and effect of biochar on nitrogen and carbon dynamics in soil. International Journal of Advanced Biological and Biomedical Research, 2, 249, 2012.

34. YAKOUT S.M. Physicochemical characteristics of biochar produced from rice straw at different pyrolysis temperature for soil amendment and removal of organics. Proceedings of the National Academy of Sciences, India Section A: Physical Sciences, 87 (2), 2074, 2017.

35. SHAH A., DARR M.J., DALLUGE D., MEDIC D., WEBSTER K., BROWN R.C. Physicochemical properties of bio-oil and biochar produced by fast pyrolysis of stored single-pass corn stover and cobs. Bioresource Technology, 125, 348, 2012.

36. LIU T., LIU B., ZHANG W. Nutrients and heavy metals in biochar produced by sewage sludge pyrolysis: its application in soil amendment. Polish Journal of Environmental Studies, 23, 271, 2014.

37. CHEN T., ZHANG Y., WANG H., LU W., ZHOU Z., ZHANG Y., REN L. Influence of pyrolysis temperature on characteristics and heavy metal adsorptive performance of biochar derived from municipal sewage sludge. Bioresource technology, 164, 47, 2014.

38. LIANG B., LEHMANN J., SOLOMON D., KINYANGI J., GROSSMAN J., O'NEILL B., SKJEMSTAD J.O, THIES J., LUIZÃO F.J., PETERSEN J., NEVES E.G. Black carbon increases Cation Exchange Capacity in soils. Soil Science Society of America Journal, 70, 1719, 2006. 
39. MUNERA-ECHEVERRI J.L., MARTINSEN V., STRAND L.T., ZIVANOVIC V., CORNELISSEN G., MULDER J. Cation exchange capacity of biochar: An urgent method modification. Science of the Total Environment, 642, 190, 2018.

40. TAKAYA C.A., FLETCHER L.A., SINGH S., ANYIKUDE K.U., ROSS A.B. Phosphate and ammonium sorption capacity of biochar and hydrochar from different wastes. Chemosphere, 145, 518, 2016.

41. MARY G.S., SUGUMARAN P., NIVEDITHA S., RAMALAKSHMI B., RAVICHANDRAN P., SESHADRI S. Production, characterization and evaluation of biochar from pod (Pisum sativum), leaf (Brassica oleracea) and peel (Citrus sinensis) wastes. International Journal of Recycling of Organic Waste in Agriculture, 5, 43, 2016.

42. SUMAYYA S.S., MURUGAN K. Phytochemical screening, RP-HPLC and FTIR Analysis of Kappaphycus alvarezii (Doty) Doty EX PC Silva: Macro red algae. Journal of Pharmacognosy and Phytochemistry, 6 (1), 325, 2017.

43. TYTLAK A., OLESZCZUK P., DOBROWOLSKI R. Sorption and desorption of $\mathrm{Cr}$ (VI) ions from water by biochars in different environmental conditions. Environmental Science and Pollution Research, 22, 5985, 2015.
44. ALTAMEME H.J.M. Phytochemical analysis of Frankenia aucheri Jaub. et Spach (Frankeniaceae) by GC-MS and ftir techniques. Plant Archives, 18 (2), 2263, 2018.

45. CHANDRA S. Fourier transform infrared (Ft-Ir) spectroscopic analysis of Nicotiana plumbaginifolia (Solanaceae). Journal of Medicinal Plants, 7 (1), 82, 2019.

46. SHWETA K., JHA H. Rice husk extracted lignin-TEOS biocomposites: effects of acetylation and silane surface treatments for application in nickel removal. Biotechnology Reports, 7, 95, 2015.

47. BRUNAUER S., EMMETT P.H., TELLER E. Adsorption of gases in multimolecular layers. Journal of the American Chemical Society, 60, 309, 1938.

48. SULIMAN W., HARSH J.B., ABU-LAIL N.I., FORTUNA A.M., DALLMEYER I., GARCIA-PEREZ M. Influence of feedstock source and pyrolysis temperature on biochar bulk and surface properties. Biomass and Bioenergy, 84, 37, 2016.

49. GIL M.V., RIAZA J., ALVAREZ L., PEVIDA C., PIS J.J., RUBIERA F. A study of oxy-coal combustion with steam addition and biomass blending by thermogravimetric analysis. Journal of Thermal Analysis and Calorimetry, 109, 49, 2012. 